\title{
THE ARRANGEMENT CONCEPTS FOR ENVIRONMENTALLY SUSTAINABLE HOUSING LAND EFFICIENCY
}

\author{
Desy Rahmadaniyati*, Rika Kisnarini **, Dewi Septanti ** \\ *) Master Student, Department of Architecture, Faculty of Civil Engineering and \\ Planning, Institute of Technology Sepuluh Nopember, Indonesia \\ e-mail: desydr@gmail.com
}

**) Lecturer, Department of Architecture, Faculty of Civil Engineering and Planning, Institute of Technology Sepuluh Nopember, Indonesia e-mail: r.kisnarini@gmail.com; dewiseptanti@gmail.com

\begin{abstract}
The issue of global urbanization gives rise to variety of urban phenomena, including the urban land scarcity and the high demand for decent dwellings. On one hand, in response to the land scarcity, the urban housing developments should be directed to a sustainable process that can take place between generations. On the other hand, housing developments also have direct impacts on the environment quality degradation. Thus, further learnings about more efficient use for housing land are needed, one of which can be learned from the already built formal housing designs in Indonesia. Therefore, this study aims to propose concepts for formal housing land arrangement to ensure the environmental sustainability. The case study of this research is Taman Wisata Regency located on the border of the city of Surabaya and Gresik, Indonesia. The data of field's existing conditions, potentials, and problems, were collected through observation and documentation. The data were analyzed descriptive and qualitative based on the criteria of sustainable housing from UN-Habitat. The results show that the land efficiency on Taman Wisata Regency can be done in the form of rearrangement proposal of prone area anticipation, the opening of inbound access from one-gate to two-gates system, the arrangement of road's circulation and proportion, the maximization of green open spaces, and also quality improvement of other infrastructures such as drainage and waste management. The results of this study are expected to be used as reference for planners, designers or developers, in creating the environmentally sustainable housing land.
\end{abstract}

Keywords: Housing, Land arrangement, Sustainable housing environment 


\section{INTRODUCTION}

The issue of urbanization is demanding that urban land should be able to accommodate variety of people's needs and activities, including for a decent, affordable, and precisely located housing (UN, 2014; UN Habitat, 2011). As basic life requirement, the housing sector becomes an economic resource for many countries and also addresses diverse indicators of human life quality improvement (UN Habitat, 2011). The existence of adequate housing also raises up stability and social inclusion amongst community, as well as presents sustainable environment. (Owoeye and Adedeji, 2015).

In dealing with urbanization, urban development should be controlled through sustainable principles (UN, 2014). The principles of sustainability should also be applied on housing since it involves not only functional and physical issues, but also associated with other life dimensions, such as social, economic, cultural, technological, ecological, and political (Martanto, 2012). To that end, the housing development in urban areas need to be continued from time to time, taking into account the high demand for housing and the increasing land scarcity. Furthermore, sustainable housing leads to realization of sustainable settlements, that in the end it supports sustainable cities (UN Habitat 2005).

One of the aspects that must be highlighted about housing development is its impacts on environmental degradation. (Uttara, et al, 2012; Harte, 2007). The importance of ecological aspect of housing has also been discussed on Agenda 21, stating that housing needs for planned for a healthy, safe, and green environment, as well as should be controlled in an environmentally efficient, effective and sustainable way (UN, 1996). In Indonesia, the government has already sought to do sustainable development of housing particularly in environmental context, as stated in UU RI (The Law of The Republic of Indonesia) concerning Housing and Settlement that housing needs to be built to (1) meet the requirements of the technical, ecological, and administrative; (2) monitor the environmentally affected area, and (3) manage environment based on the available planning (UU RI, 1/2011).

In this regard, actualizing the efficient and sustainable housing can be done by learning the built formal housing design, since it is considered as a form of housing that comply with proper rules. In total of $20 \%$ of dwellings in Indonesia are formal housing owned by Indonesian government or private parties, which were built systematically with good planning. While the rest are informal housing belonging to citizens which were not accompanied by adequate planning or followed formal rules from the government (Widoyoko, 2007; Ministry of Housing, 2009 in Cahyadini, 2009). Therefore, further studies on formal residential land use can be done through evaluating its design in context of efficiency to ensure the environmental sustainability. The process is then directed to the formulation of concepts for sustainable land arrangement efficiency on formal housing. 


\section{THEORY / METHODS}

\section{Housing Land Arrangement}

The term 'housing and settlements' basically involves container (including nature, shells, networks), and its contents including man and society (Doxiadis, 1968 in Goenmiandari, et al, 2010; Sastra and Marlina 2006). Based on UU RI 1/2011 concerning Housing and Settlement, 'housing' is a group of appropriate houses as part of settlement equipped with infrastructure, facilities, and public utilities. The term 'Settlement' has broader scope, consisted of several housings with infrastructure, facilities, public utilities, as well as supporting the activities of other functions. While, the term 'land' in this study refers to Kasiba and Lisiba related to housing and settlement. Kasiba (a ready to built-region) is a certain land that its physical (including infrastructure, facilities, and utilities) prepared for the construction of big scaled residential development area, and Lisiba (a ready to builtenvironment) has smaller scope, which reserved for residential development with limited parcels of land. (UU RI, 1/2011).

While the term arrangement of land settlement can be customized with several regulations in Indonesia. In the Law of The Republic of Indonesia Number 26 of 2007 concerning Spatial Planning, it is stated that the arrangement (of space) is a series of planning, utilization, and controlling (the use of space) process (UU RI, 26/2007). More specifically, The Law of The Republic of Indonesia Number 1/2011 concerning Housing and Settlement pointed out that the arrangement is a step of housing management through improvements so that it could run in accordance with its objectives (UU RI, 1/2011). The arrangement effort relates to the process of making a land more efficient. The term 'efficiency' is associated with the accuracy, usability, and appropriateness in running a thing, through the right and precise way in order to produce optimal results, as well as minimizing the use of time, effort, and cost. (KBBI, 2001; Karim, 2006). In this case, the efficiency term is directed to the housing arrangement and settlement context.

Thus, it is concluded that housing land arrangement is one of proper ways to fix an already built housing environment, attempting to optimize the use of land in its neighborhood through improvement and controlling effort in order to reach the sustainability. Aspects to be considered in this regard are housing facilities, infrastructure, public utilities, and other supporting facilities.

\section{Sustainable Housing Concept and its Ecological Aspect}

Sustainable housing is a utilization of land and space in order to meet people's needs of place to live and to work. To keep the process going over time, it should involves many aspects of life such as economic, environmental, social, and cultural. (Timmer and Kate, 2006; UN-Habitat, 2012). It is also comprehensive, reaching the level of the macro, meso, and micro in urban context. Other than that, sustainable housing has the potential to boost the economic development, the environmental managings and services, as well as the quality of life and social equality. Moreover, it can also prevent wide range of housing problems (UN-Habitat, 2012). Specifically, 
sustainable housing highlights three main aspects, which are the environment (to protect the natural environment, to use natural resources wisely, and to prevent and adapt the climate changes), the people (to accommodate socio-cultural equality, and guarantee the right to decent, affordable, and well-located dwelling), and the prosperity (to perform responsive and competitive economic development) (UNHabitat, 2012).

In addition, the environmental aspect of housing needs to be considered particularly because of several reasons, among others are its development that requires environmental resources, household's activities that directly pollute the environment, and also the residential neighborhood that is prone to natural disasters (UN-Habitat, 2012). The environmentally sustainable housing in this research is focused to meso (city) and micro (neighborhood) scale according to UN Habitat (2012). On the meso scale, the criteria are (1) occupying an area with good location and population density, and got easy access to infrastructure; (2) has serviced land located on safe and green environment; (3) protecting ecosystems and biodiversity; (4) emphasizing sustainable infrastructure, public transport, pedestrians, and energy systems; and (5) managing waste and reusing it. While on the micro scale, the criteria are (1) using energy and resources efficiently; (2) designing green building using local materials and contruction techniques; (3) designing the environmentalfriendly sanitation systems; (4) using affordable resources; and (5) creating resilience and adaptive buildings (UN-Habitat, 2012).

Based on all notions above, followings are aspects to be considered related to the arrangement of built formal housing and its environmental sustainability:

1. The environmentally safe location and the ease of access to urban infrastructure, including potential / challenges of the land, proximity to various urban facilities, as well as the completeness of local amenities

2. Protection of surrounding ecosystems and biodiversity, including the provision of green area with good proportion of softscape and hardscape

3. Waste management and recycling system, including the system of storage, transport, and management.

4. Adequate sanitation and drainage system with safe material, including the sewage system, catchment area, and puddle prevention

5. Environmental friendly housing infrastructure, including greeneries, shadings / heat area prevention, noise and air pollution managements, adequate and effective circulation system, and efficient street lightings.

\section{Research Methods}

The case study of this research is an available formal housing (already developed) namely Taman Wisata Regency, located on the border of the city of Surabaya and Gresik, East Java, Indonesia. This residence can be accessed from Wisma Lidah Kulon Street, but should be reached through Raya Menganti Street and Raya Wisma Lidah Kulon Street. On the east of this residence, there are settlements on Bangkingan Street, while on the west and south is the Gresik city area. In its planning, the residence consists of 500 houses divided into some types. While the scope of this study (shown with orange shades on Figure 1) are 291 built houses, 
observed through Google Map and its marketing blogs. It consists of 78 units of type 36,108 units of type 38, 56 units of type 55, and 49 units of type 60.

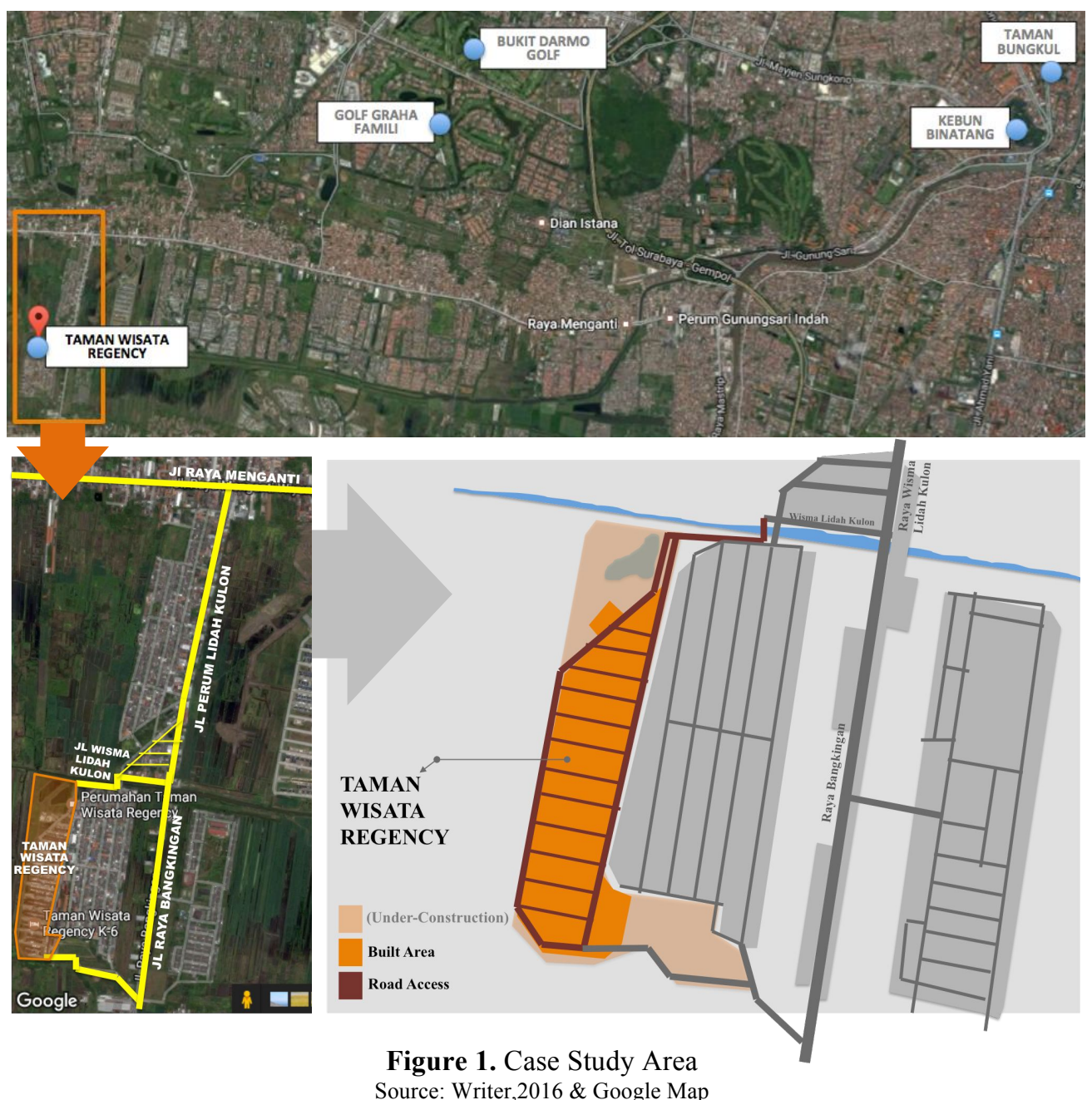

The data are collected through observation and documentational study from articles as well as housing advertisements. The findings are analyzed and presented qualitatively descriptive by the following steps: (1) identification of existing conditions, potentials and problems on the study object; (2) analysis of the previous findings based on the environmentally sustainable housing principles obtained from the results of literature review; (3) concept formulation for efficient and sustainable land arrangement of formal housing on Taman Wisata Regency. The proposed concepts are also adapted to the prevailing local regulations of spatial planning from government. (See Figure 2) 


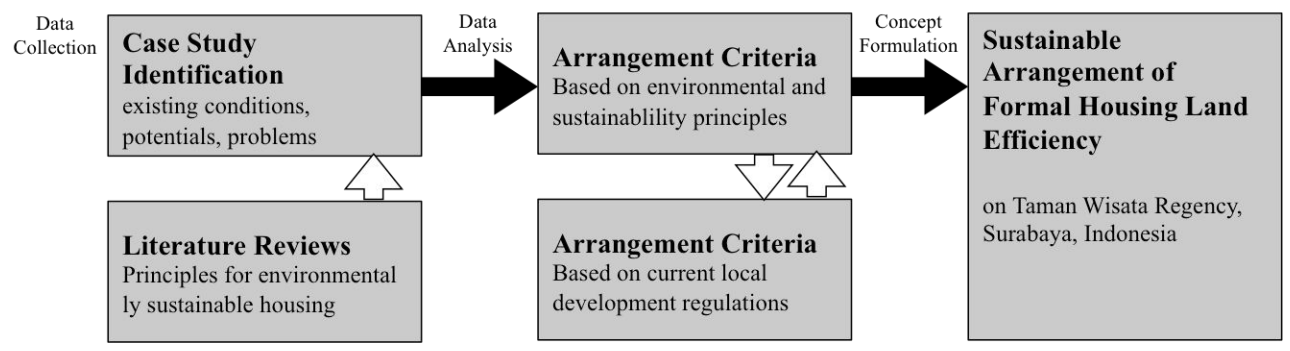

Figure 2. The Scheme of the Reseach Methods

Source: Author, 2016

\section{RESULTS AND DISCUSSIONS}

\section{Case Study Reviews based on Environmentally Sustainable Housing Principles and Local Development Regulations}

Taman Wisata Regency has been planned well in terms of building design, proximity to public facilities, and greeneries. However, the residence has some shortcomings and problems needed to be optimized. The prominent problem is the close distance of this housing to a tower of SUTT (high voltage electrical tower), while the others are related to local facilities, vulnerable entrance, lack of green areas, waste disposal system, and drainage covering. Based on the five rules obtained on literatures, Taman Wisata Regency need to be reorganized, especially in context of space allotment, facilities completion, and infrastructures improvement. Thus, the potential of arrangements for the residence are readjustments of space use around the SUTT tower, consideration for alternative entrances and signages, addition of supplementary facilities, improvement of electrical networks and street lightings, and enhancement of the exsisting infrastructures quality. These include several things that will be respectively explained in the next section.

Regarding local regulations, in accordance with The Detailed Spatial Planning on Wiyung Region (RDTRK UP. Wiyung) in year of 2007, Taman Wisata Regency is located in area planned for formal housings and green open space conservation. The comparison of residential area and the green open spaces should be $7: 3$. In amount of $5 \%$, the green area can be used as sports field, median strips, and particular open space for SUTT tower that is 6 meters in minimum. Other than that, based on The Regulation of The Minister of Energy and Mineral Resources of The Republic of Indonesia Number 18 Year 2015 (PerMen. ESDM RI 18/2015) and The Mandatory Indonesian National Standard of 2002 (SNI, 2002), the safe land use surrounding the tower of SUTT is outside the minimum limits of 12.5-18 meters from its vertical conductor, and 17 meters from its horizontal axis. In conclusion, all the considerations above developed into the whole arrangement criteria. 


\section{The Criteria of Land Arrangement Efficiency on Taman Wisata Regency}

Followings are the arrangement criteria for proposing the concepts of Taman Wisata Regency's land efficiency, in terms of environmental aspects:

1. Re-arrangements of the SUTT tower surroundings, maximized as green spaces but not actively used within $6 \mathrm{~m}$ radius. The closest building to this tower must be located as far as $17 \mathrm{~m}$.

2. Establishment of alternative entrance, opening new access from southern part (Raya Bangkingan St.), provided with its own gate and security post.

3. Readjustment of the roads proportion and its circulation path if needed.

4. Optimization of green spaces in various areas such as entrance, hook areas, parks, road edges, and median strips; Also provision of additional facilities.

5. Quality improvement of existing infrastructure including waste disposal drainage system, coverings, residence fencings, electricity system and street lightings.

\section{The Concepts of Land Arrangement Efficiency on Taman Wisata Regency}

Followings (Figure 3) are the proposed concepts for Taman Wisata Regency rearrangement based on obtained criteria:

\section{Passive Green Space Near the SUTT Tower}

The communal park for Taman Wisata Regency is concentrated around the SUTT tower. At certain radius, which is 6 meters from its axis, the open space function should be disabled or being passive (only for tower maintenance). Outside from that, the park can be used actively (see Figure 3 ).
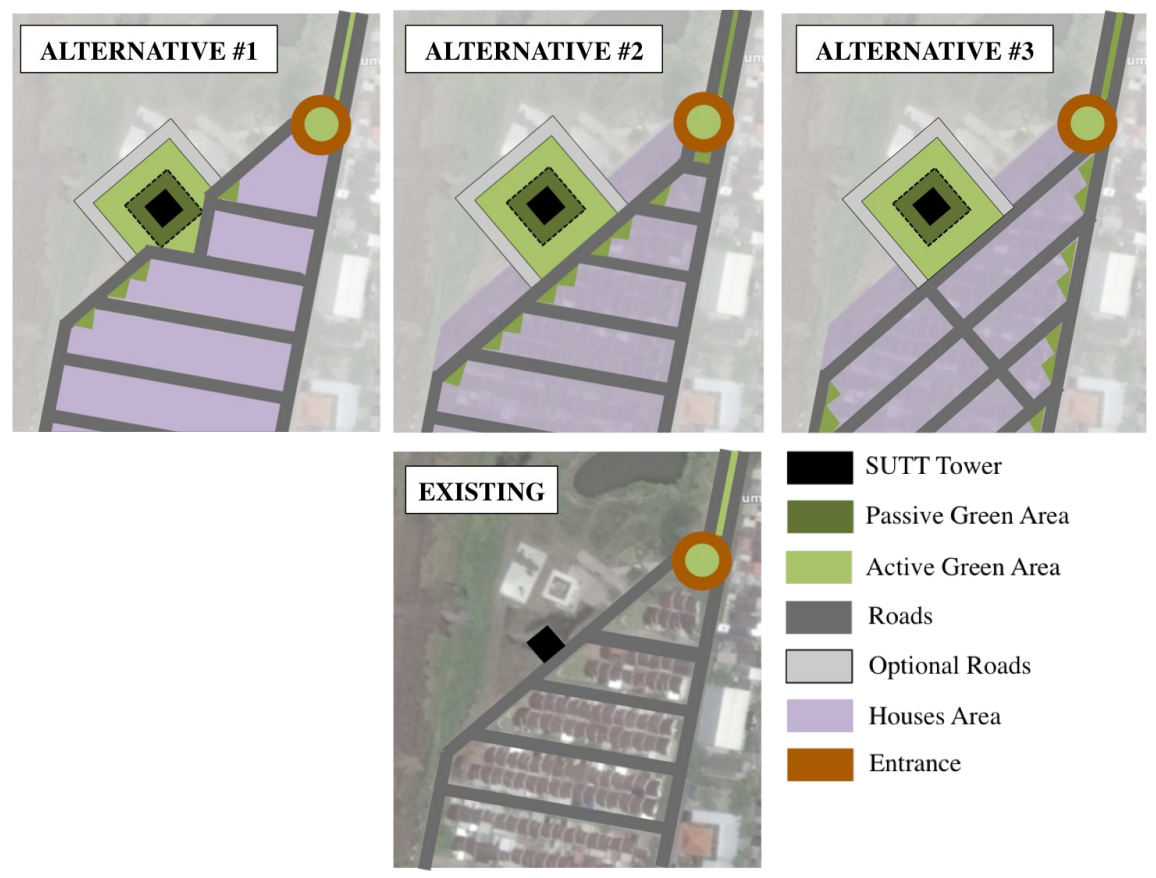

Figure 3. Proposed Area Near the Electricity Tower (SUTT) 
It need to be ascertained that the minimum distance between the SUTT tower and buildings should be 17 meters away for safety and health issue. Currently, the distance of existing houses is already met the minimum limit, but there is a mosque located only about 12 meters from the tower. Figure 3 shows some alternatives of proposed green space near the tower.

\section{Signages and Two Gate System}

Some signages should be provided at certain points to indicate the presence and specific location of Taman Wisata Regency. The signages are proposed to be placed on: (1) the intersection of Raya Menganti St and Raya Wisma Lidah Kulon St; (2) the intersection of Raya Wisma Lidah Kulon St and Wisma Lidah Kulon St; (3) the artificial bridge of Taman Wisata Regency located on Wisma Lidah Kulon St; and (4) the new access from Raya Bangkingan St. (See Figure 4)

Moreover, considering the concurrent development of Taman Wisata Regency which began to expand its area on the southern part, a new alternative access is proposed. The one gate system should be changed into two gate system in order to enhance the safety and security issue. (See Figure 4). The facility of the additional entrance is designed similarly as the preexistent one, equipped with gate, security post, and green space. Since the new entrance has direct access to the most exclusive cluster in this residence, the facility should be more advanced. The gate only be opened in a more strict hours and be accessed only by local residents using ID card.
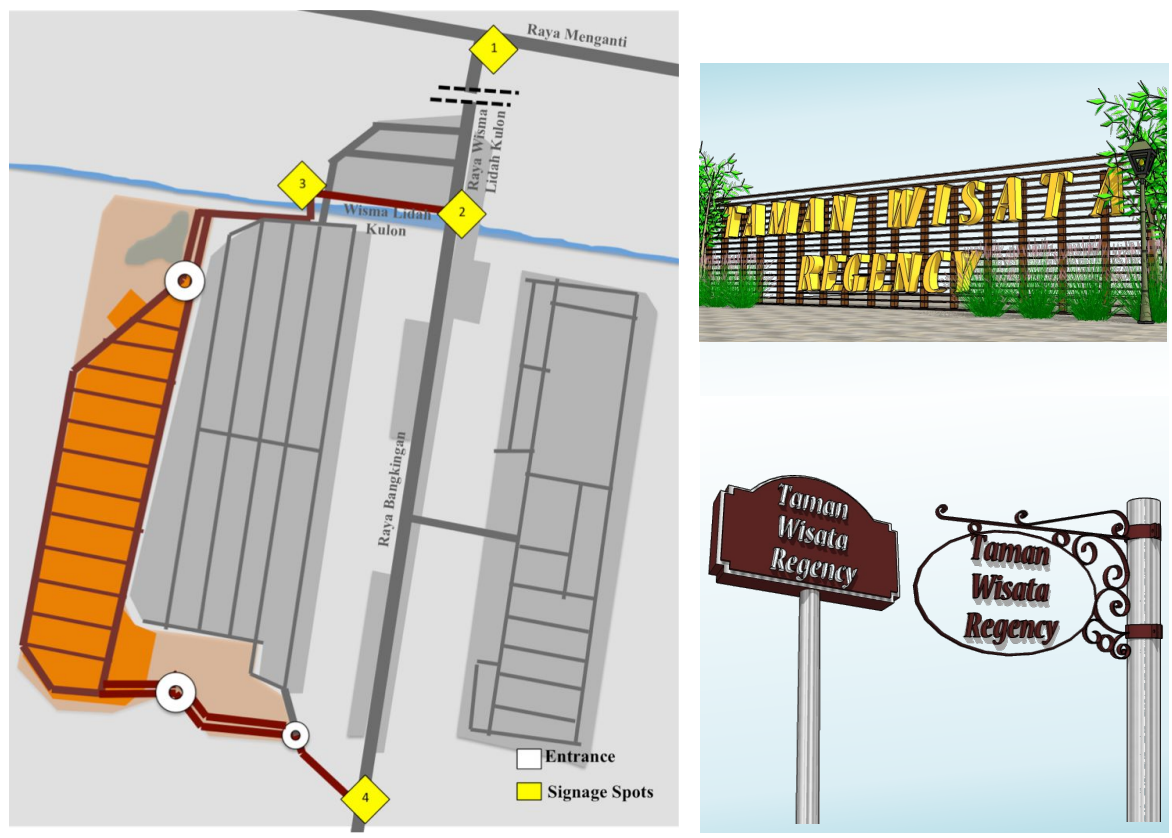

Figure 4. Proposed Locations of Signages and Entrances; Signage Ideas Source: Author, 2016 


\section{Additional Greeneries and Multifunctional Green Spaces}

Greeneries are proposed to be added in certain places such as the arrival space, hook areas, or road edges in the form of trees, shrubs, or vertical garden. The housing fences also should be elevated to 3 meters or more, and one of its sides are used for vertical gardens. (See Figure 5).
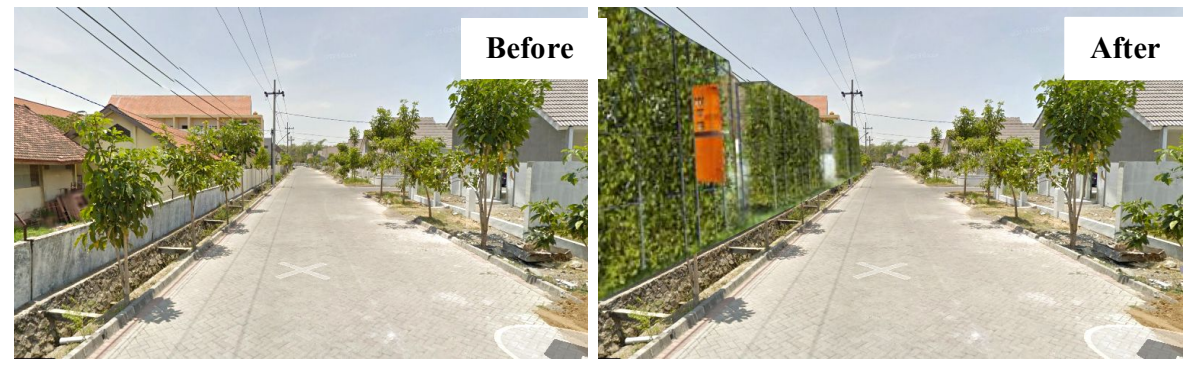

Figure 5. Ideas for Vertical Garden on Housing Fences Source: Google Street View, 2016

Additionally, the communal green space is optimized as both physical and social space as its original design concepts. It is also equipped with existing mosque. Furthermore, it is still possible to add other facilities such as healthcare or educational facilities like library or kindergarten, but they are optional and will not detract the residence quality if they do not exist.

\section{Re-Arrangement of Road Proportion}

The street proportion is set to be 8 meters width for the primary path and 5.5 meters width for secondary path in all clusters. On the primary streets, 1.2 meters width of pedestrian way is given on one side, and be simultaneously used for jogging track and bike lanes through different color of the paving. While on the secondary path, the road is designed to have a $30 \mathrm{~cm}$ width of drainage and $45 \mathrm{~cm}$ width of greeneries on both sides. (See Figure 6). This proposed concept is an elimination of existing road width, more efficient yet still meet the rules, and able to accommodate greeneries.

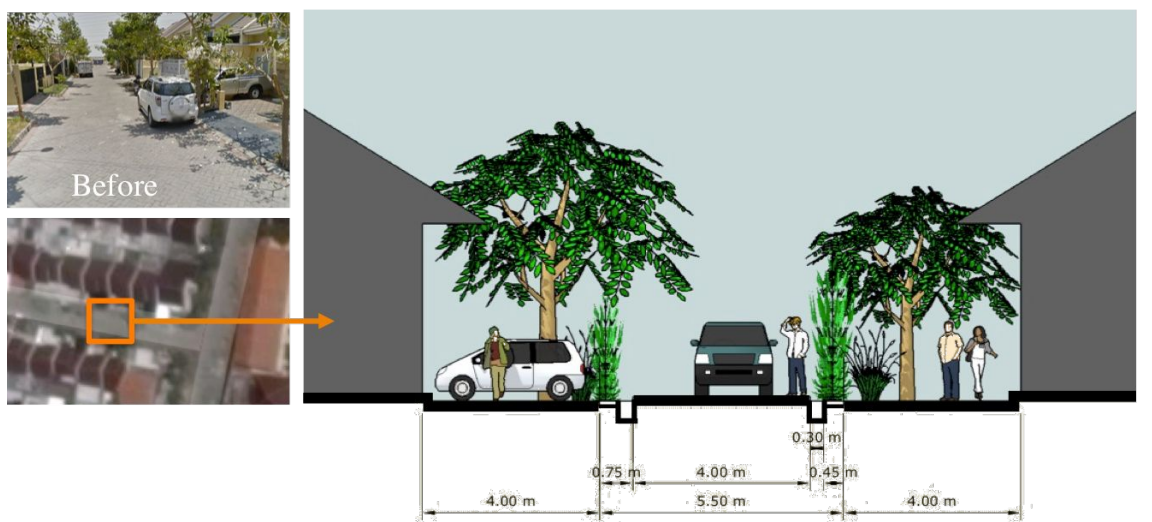

Figure 6. The Elimination Concept of Existing Road Width 
Other than that, the exsisting clusters placement is already good that the most exclusive one is located far from the SUTT tower, so it is not necessary to do cluster rearrangement.

\section{Quality Enhancement of Other Existing Infrastructures}

Discussing about safety, the residence fencings need to be improved so it is not only functioning as territorial divider but also as protector and even aesthetics element. (See Figure 5). Still about aesthetic, the electrical wirings should be rearranged to be an underground system, and the lamp posts also should be replaced with more aesthetic design in order to create tidier and better visual ambience. Besides, existing communal garbage bin located before the entrance also should be resolved with better quality container that is cleaner, more organized, and easier to maintain even though it is placed on open space. The surrounding area need to be visually integrated with other housing facilities, such as through similar colour.

At last, discussing about existing gutters, the alternative ways for improving its covering are the opened drainage system with grill cover (See Figure 7), or the closed one with several openings at certain distances. This is required to avoid waterloggings and to ease maintenance process.

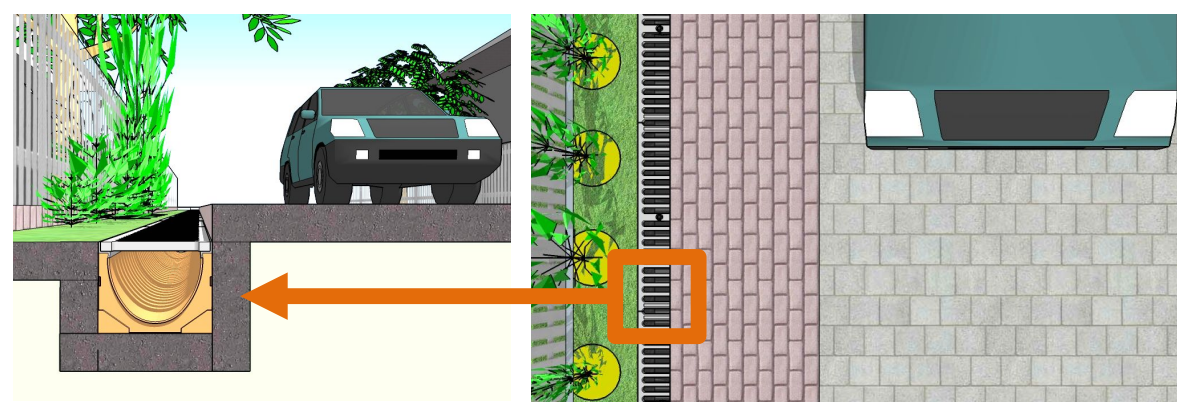

Figure 7. Proposed Concept for Drainage Covering Source: Author, 2016

\section{CONCLUSIONS}

Taman Wisata Regency is a formal housing in Indonesia located between Surabaya and Gresik City. Reviewed from the environmentally sustainable context, this residence has been planned and realized well, but still has shortcomings that need to be optimized. The prominent problem is the closeness of the residence to electricity tower (SUTT), and the others are related to local facilities, vulnerable access, lack of green areas, waste disposal, and drainage covering. The concept of land arrangement efficiency on Taman Wisata Regency is associated with the utilization of prone area, the opening of new access becoming two gate systems completed with the signages, the redesign of road proportion, the optimation of green spaces, and the quality improvement of existing infrastructures. 
This study is an instance of formal housing improvement in terms of sustainable land efficiency, which also can be applied on informal settlement context. However, the weakness of this study is lack of data collection technique resulting in limited case study coverage. For future research, more obvious study area should be determined to ease the analysis and concept formulation. All the more, methods and indicators in this study can be used for similar research with contextual adaptations.

\section{ACKNOWLEDGMENT}

I would like to express great appreciation to my lecturers, Mrs. Rika and Mrs. Dewi for the valuable suggestions during the planning and development of this research.

\section{REFERENCES}

. (2001), Kamus Besar Bahasa Indonesia. Pustaka Sinar Harapan, Jakarta

Cahyadini, S. (2009). Housing for The Poor Widow in Urban Area. A Study of Housing for Widow in Bangil, East Java, Indonesia. Dissertation, Lund University, Sweden.

Harte, J (2007), Human Population as A Dynamic Factor in Environmental Degradation. Popul Environ 28. DOI 10.1007/s11111-007-0048-3. Springer Science and Business Media, LLC.

Karim, A. (2006), Bank Islam-Analisis Fiqih dan Keuangan. PT. Raja Grafindo Persada, Jakarta.

Martanto, A. (2012), Kajian Efisiensi Penggunaan Lahan dan Pola Persebaran Perumahan di Ibukota Kabupaten Purwakarta. Jurnal Pembangunan Wilayah dan Kota. Volume 8 (3). Biro Penerbit Planologi Undip, Semarang.

Owoeye,O.J and Adedeji, Y.M.D (2015), Urban Land Acquisition for Sustainable Housing Delivery in Akure, Nigeria. International Journal of Developing Societies Vol. 4, No. 1, 2015. DOI: 10.11634/216817831504641. ISSN 21681783. World Scholar, USA .

Peraturan Menteri Republik Indonesia, Energi dan Sumberdaya Mineral RI No. 18 2015 tentang Ruang Bebas dan Jarak Bebas Minimum pada Saluran Udara Tegangan Tinggi, Saluran Udara Tegangan Ekstra Tinggi, dan Saluran Udara Tegangan Tinggi Arus Searah untuk Penyaluran Tenaga Listrik.

RDTRK Kota Surabaya (2007), UP. Wiyung.

SNI / Standard Nasional Indonesia (2002). Ruang bebas dan jarak bebas minimum pada Saluran Udara Tegangan Tinggi (SUTT) dan Saluran Udara Tegangan Ekstra Tinggi (SUTET). Badan Standardisasi Nasional. SNI 04-6918-2002.

Timmer,V and Kate, N. (2006). The Sustainable Region Initiative. The World Urban Forum : Vancouver Working Group Discussion Paper. International Center for Sustainable Cities, Canada. 
UN-Habitat. (2011), Affrodable Land and Housing in Asia. ISBN : 978-92-1132369-6. United Nations Human Settlements Programme. UNON Publishing Service Section, Nairobi.

UN-Habitat. (2012), Sustainable Housing for Sustainable Cities: A Policy Framework For Developing Countries. ISBN: 978-92-1-132488-4. UNON Publishing Service Section, Nairobi.

UN. (1996), National Report for Habitat II Republic of Indonesia. National Committee for Habitat II, Jakarta.

UN. (2014), World Urbanization Prospects. The 2014 Revision - Highlights. ISBN 978-92-1-151517-6. Deptartment of Economic and Social Affairs : New York.

Uttara, S, et all. (2012), Impacts of Urbanization on Environment. International Journal of Research in Engineering \& Applied Sciences. Vol.2 Issue 2. ISSN: 2249-3905. Yeshwantrao Chavan College of Engineering, India.

UU Republik Indonesia No.26 Tahun 2007 tentang Penataan Ruang

UU Republik Indonesia No.1 Tahun 2011 tentang Perumahan dan Kawasan Permukiman.

Widoyoko, D (2007), Good Governance and Provision of affordable Housing in DKI Jakarta. From the Partnering to Combat Corruption series. Editor : M. Sohail. ISBN : 9781843801160 . Department for International Development or WEDC (Water, Engineering, and Development Centre), Loughborough University, UK. 